Наулік Н., Горзов А.

Особливості правового статусу керівника державної служби в місцевій прокуратурі

УДК 343.163

\title{
Наталія Наулік,
}

кандидат юридичних наук, доиент, начальник відділу підвищення кваліфікачіі державних службовців органів прокуратури Інституту підвищення кваліфікації прокурорів Національної академії прокуратури України

\section{Анатолій Горзов,}

кандидат юридичних наук, заступник начальника відділу підвищення кваліфікаиії державних службовців органів прокуратури Інституту підвищення кваліфікаџї прокурорів Національної академії прокуратури України

\section{ОСОБЛИВОСТІ ПРАВОВОГО СТАТУСУ КЕРІВНИКА ДЕРЖАВНОЇ СЛУЖБИ В МІСЦЕВІЙ ПРОКУРАТУРІ}

Проаналізовано чинне законодавство та закріплення в ньому правового статусу керівника державної служби в місиевій прокуратурі. Визначено основні термінологічні розбіжності в законодавстві та запропоновано можливі варіанти врегулювання правової колізії при врегулювання означеного питання.

Ключові слова: керівник місиевої прокуратури, правовий статус керівника прокуратури, прокуратура, державна служба, керівник державної служби, безпосередній керівник.

\section{Наулик Н., Горзов А.}

Особенности правового статуса руководителя государственной службы в местной прокуратуре

Проанализированы действующее законодательство и закрепление в нем правового статуса руководителя государственной службы в местной прокуратуре. Определень основные терминологические расхождения в законодательстве и предложень возможные варианты урегулирования правовой коллизии при урегулирования указанного вопроса.

Ключевые слова: руководитель местной прокуратуры, правовой статус руководителя прокуратуры, прокуратура, государственная служба, руководитель государственной службы, непосредственный руководитель.

\section{Naulik N., Gorzov A.}

Features of the legal status of the civil service manager in local prosecutor

The article analyzes the current legislation and enshrines the legal status of the head of the civil service at the local prosecutor's office in it. The basic terminological discrepancies in the legislation are defined and possible options for resolving a legal conflict in the settlement of this issue are proposed.

Keywords: head of the local prosecutor's office, legal status of the head of the prosecutor's office, prosecutor's office, civil service, head the of the civil service, immediate supervisor.

Постановка проблеми. Україна поступово виконує взяті на себе зобов’ язання перед європейським товариством щодо реформування правоохоронної та судової системи. Так, 14 жовтня 2014 р. Верховною Радою України прийнято новий Закон України «Про прокуратуру», відповідно до якого прокуратура України становить єдину систему, яка здійснює встановлені Конституцією України функції з метою захисту прав і свобод людини, загальних інтересів суспільства та держави [1]. Законом визначено систему прокуратури та статус прокурора. 2 вересня 2016 р. набрали чинності зміни до Конституції України [2], якими прокуратуру в Україні віднесено до правосуддя, визначено нові функції прокуратури.

Відповідно до ст. 14 Закону України «Про прокуратуру», у структурі органів прокуратури серед інших встановлюються посади державних службовців, діяльність яких регулюється цим Законом та іншими законодавчими актами України.

Реформування органів прокуратури в Україні співпало із реформуванням державної служби. 10 грудня 2015 р. прийнято Закон України «Про державну службу», який вступив в дію 1 травня 2016 р. Новий Закон визначає принципи, правові та організаційні засади забезпечення публічної, професійної, політично неупередженої, ефективної, орієнтованої на громадян державної служби, яка функціонує в інтересах держави і суспільства, а також порядок реалізації громадянами України права рівного доступу до державної служби, що базується на їхніх особистих якостях та досягненнях [3].

() Наталія Наулік, Анатолій Горзов, 2018 
Аналіз останніх досліджень і публікацій. Дослідженнями проблем нормативно-правового регулювання правового статусу прокурора, керівника прокуратури та керівника державної служби в місцевій прокуратурі займались такі українські науковці: Р. Басараб, А. Горзов, В. Долежан, О. Долгий, Ю. Дьомін, М. Косюта, Н. Наулік, О. Назарук та ін.

Постановка завдання. Метою даного дослідження є виокремлення особливостей правового статусу керівника державної служби в місцевій прокуратурі, з’ясування його повноважень та знаходження вирішення правових колізій.

Виклад основного матеріалу. Відповідно до Закону, державна служба - це публічна, професійна, політично неупереджена діяльність із практичного виконання завдань і функцій держави. Державний службовець - це громадянин України, який займає посаду державної служби в органі державної влади, іншому державному органі, його апараті (секретаріаті) (далі - державний орган), одержує заробітну плату за рахунок коштів державного бюджету та здійснює встановлені для цієї посади повноваження, безпосередньо пов'язані з виконанням завдань і функцій такого державного органу, а також дотримується принципів державної служби.

В органах прокуратури працює понад дві тисячі державних службовців, з них понад дев'ятсот державних службовців категорії В - у місцевих прокуратурах, на яких поширюється дія Закону України «Про державну службу».

Ст. 12 Закону України «Про прокуратуру» визначено, що у системі прокуратури України діють місцеві прокуратури. Місцеву прокуратуру очолює керівник місцевої прокуратури, який є прокурором органу прокуратури відповідно до п. 14 ч. 1 ст. 15 Закону [2].

Досліджуючи особливості правового статусу керівника державної служби в місцевій прокуратурі, варто звернутись до етимологічного значення понять «статус», «правовий статус». Так, поняття статусу розглядається як певний стан чого-небудь [4, с. 1191]. Правовий статус (лат. status - становище) тлумачиться як сукупність прав і обов'язків фізичних та юридичних осіб [5, с. 693].

У теорії права розрізняють загальний, галузевий та спеціальний правовий статуси. Загальний правовий статус закріплений Конституцією та законодавством України і визначає основи правового становища особи в державі. Галузевий статус розглядається як сукупність прав і обов'язків фізичних та юридичних осіб, що регламентується нормами кількох галузей права, а спеціальний - визначається нормами спеціального законодавства [5, с. 693]. Отже, нормами спеціального законодавства визначено правовий статус прокурора, керівника місцевої прокуратури та керівника державної служби в місцевій прокуратурі через його повноваження.

У ст. 13 Закону України «Про прокуратуру» закріплено повноваження керівника місцевої прокуратури, серед яких: представляти місцеву прокуратуру у зносинах з органами державної влади, іншими державними органами, органами місцевого самоврядування, особами, підприємствами, установами та організаціями; організовувати діяльність місцевої прокуратури; у десятиденний строк із дня вивільнення посади повідомляти Кваліфікаційно-дисциплінарну комісію прокурорів про наявність вакантної або тимчасово вакантної посади у місцевій прокуратурі; забезпечувати виконання вимог щодо підвищення кваліфікації прокурорів місцевої прокуратури; виконувати інші повноваження, передбачені цим та іншими законами України.

Відповідно до п. 13 ч. 3 ст. 3 Закону України «Про державну службу», його дія не поширюється на прокурорів.

Однак відповідно до ч. 8 ст. 91 Закону, повноваження керівника державної служби в органах прокуратури здійснюс керівник відповідного органу прокуратури.

Тому для належної організації діяльності керівник місцевої прокуратури повинен знати та розуміти норми нового Закону України «Про державну службу».

Відповідно до Закону, керівник державної служби в державному органі (далі-керівник державної служби) - посадова особа, яка займає вищу посаду державної служби в державному органі, до посадових обов'язків якої належить здійснення повноважень 3 питань державної служби та організації роботи інших працівників у цьому органі. І це визначення не стосусться керівника місцевої прокуратури, оскільки він не с керівником державної служби в місцевій прокуратурі, а лише виконус його повноваження.

Безпосередній керівник - найближчий керівник, якому прямо підпорядкований державний службовець. Дане визначення є важливим при діяльності державних службовців, які працюють у віддалених структурних підрозділах місцевої прокуратури.

Враховуючи вищевказані положення Закону, безпосередній керівник державного службовця та керівник місцевої прокуратури - поняття тотожні, які не можна розмежовувати, тобто державні службовці 
Наулік Н., Горзов А.

Особливості правового статусу керівника державної служби в місцевій прокуратурі

місцевої прокуратури безпосередньо підпорядковуються керівнику місцевої прокуратури. Однак за порушення прав державних службовців керівник місцевої прокуратури нестиме відповідальність за Законом України «Про прокуратуру» (через Кваліфікаційно-дисциплінарну комісію прокурорів).

Аналізуючи ч. 2 ст. 17 Закону України «Про державну службу», керівник місцевої прокуратури (керівник державної служби в місцевій прокуратурі):

1) організовує планування роботи з персоналом місцевої прокуратури, в тому числі організовує проведення конкурсів на зайняття вакантних посад державної служби_категорії «В», забезпечує прозорість і об'єктивність таких конкурсів;

2) забезпечує планування службової кар’єри, планове заміщення посад державної служби підготовленими фахівцями згідно з вимогами до професійної компетентності та стимулює просування по службі;

3) забезпечує своєчасне оприлюднення та передачу Національному агентству України 3 питань державної служби, інформації про вакантні посади державної служби;

4) призначає громадян України, які пройшли конкурсний відбір, на вакантні посади державної служби категорій «В» і звільняє 3 таких посад;

5) присвоює ранги державним службовцям місцевої прокуратури (стаття 39 Закону);

6) забезпечує підвищення кваліфікації державних службовців місцевої прокуратури (на сьогодні, таке підвищення забезпечуються Національною академією прокуратури України);

7) здійснює планування навчання державних службовців місцевої прокуратури з метою вдосконалення рівня володіння ними державною мовою;

8) здійснює контроль за дотриманням виконавської та службової дисципліни в місцевій прокуратурі;

9) розглядає скарги на дії або бездіяльність державних службовців відповідної місцевої прокуратури;

10) приймає у межах наданих повноважень рішення про заохочення та притягнення до дисциплінарної відповідальності державних службовців;

11) створює належні для роботи умови та їх матеріально-технічне забезпечення [3].

Крім того, Законом чітко визначено обов'язки керівника державної служби щодо забезпечення службової дисципліни (Ст. 63).

Керівник місцевої прокуратури несе відповідальність за неналежний рівень службової дисципліни і здійснює повноваження щодо притягнення державних службовців до дисциплінарної відповідальності.

3 метою забезпечення належного рівня службової дисципліни керівник державної служби в місцевій прокуратурі зобов'язаний:

1) створювати умови для виконання державними службовцями своїх посадових обов’язків і підвищення ними професійної компетентності та вимагати належного виконання посадових обов'язків;

2) здійснювати контроль за виконанням державними службовцями посадових обов'язків;

3) під час виконання посадових обов’язків керуватися публічними інтересами, суворо дотримуватися і забезпечувати дотримання Конституції, законів України та інших нормативно-правових актів, чітко формулювати накази (розпорядження) та доручення, перевіряти точність і своєчасність їх виконання;

4) забезпечувати виконання державними службовцями своїх посадових обов'язків, у тому числі шляхом застосування дисциплінарних стягнень;

5) належним чином організовувати роботу державних службовців, забезпечувати ефективне виконання завдань, що поставлені перед державним органом;

6) виховувати у державних службовців сумлінне ставлення до служби, бережливе ставлення до державного майна, підтримувати їхню ініціативу, а також вживати заходів для додержання ними правил етичної поведінки;

7) забезпечувати прозорість та об'єктивність під час оцінювання результатів службової діяльності державних службовців;

8) організовувати проведення з державними службовцями профілактичних заходів щодо запобігання вчиненню ними дисциплінарних проступків, виявляти та своєчасно припиняти їх вчинення [3].

Тому варто звернути увагу, що керівник місцевої прокуратури, який в установленому Законом України «Про державну службу» порядку не вжив заходів для притягнення підпорядкованого йому державного службовця до дисциплінарної відповідальності за вчинений дисциплінарний проступок, а також не подав матеріали про вчинення державним службовцем адміністративного проступку, корупційного або пов’язаного з корупцією правопорушення, злочину до органу, уповноваженого розглядати справи про такі правопорушення, несе відповідальність згідно із законом. 
Враховуючи вищезазначене, очевидно, що до відповідальності за порушення норм Закону України «Про державну службу» в межах реалізації повноважень керівника державної служби та дотримання прав державних службовців, зокрема захисту прав на державну службу, керівника місцевої прокуратури (прокурор) можна притягнути до дисциплінарної відповідальності лише в порядку, передбаченому Законом України «Про прокуратуру» через Кваліфікаційно-дисциплінарну комісію прокурорів.

У Законі чітко врегульовані питання підпорядкування державного службовця та виконання наказу (розпорядження), доручення керівника (ст. 9 Закону України «Про державну службу»).

Державний службовець під час виконання посадових обов'язків діє у межах повноважень, визначених законом, і підпорядковується своєму безпосередньому керівнику або особі, яка виконує його обов’ язки, тобто керівнику місцевої прокуратури.

Керівник місцевої прокуратури (керівник державної служби) за результатами конкурсу на зайняття вакантної посади державної служби приймає рішення про призначення на посаду державної служби переможця конкурсу.

Відповідно до ст. 44 Закону результати службової діяльності державних службовців щороку підлягають оцінюванню для визначення якості виконання поставлених завдань, а також 3 метою прийняття рішення щодо преміювання, планування їхньої кар'єри, виявлення потреби у професійному навчанні.

Оцінювання результатів службової діяльності проводиться на підставі показників результативності, ефективності та якості, визначених з урахуванням посадових обов’язків державного службовця, а також дотримання ним правил етичної поведінки та вимог законодавства у сфері запобігання корупції.

Отже, керівник державної служби в місцевій прокуратурі (керівник відповідної прокуратури) повинен здійснювати оцінювання результатів службової діяльності державних службовців місцевої прокуратури. Висновок щодо результатів оцінювання службової діяльності затверджується наказом керівника місцевої прокуратури. Державного службовця ознайомлюють з результатами оцінювання його службової діяльності під підпис протягом трьох календарних днів після проведення оцінювання.

За результатами оцінювання службової діяльності державного службовця йому виставляється негативна, позитивна або відмінна оцінка з ії обгрунтуванням [3].

Очевидна важлива роль керівника місцевої прокуратури у підвищенні рівня професійної компетентності державних службовців.

Відповідно до вимог ст. 48 Закону державним службовцям створюються умови для підвищення рівня професійної компетентності шляхом професійного навчання, яке проводиться постійно.

Саме керівник державної служби забезпечує:

- організацію професійного навчання державних службовців;

- підвищення кваліфікації державних службовців на робочому місці або в інших установах (організаціях);

- має право відповідно до закону закуповувати послуги, необхідні для забезпечення підвищення кваліфікації державних службовців, у підприємств, установ та організацій незалежно від форми власності, фізичних осіб.

Підвищення рівня професійної компетентності державних службовців проводиться протягом проходження служби, а підвищення кваліфікації - не рідше одного разу на три роки [3].

Державні службовці місцевих прокуратур пройшовши оцінювання своєї службової діяльності та отримавши результати разом із службою управління персоналом (або особою, яка виконує такі функції в місцевій прокуратурі) складають індивідуальну програму підвищення рівня професійної компетентності, яку затверджує керівник.

Для державних службовців органів прокуратури в Національній академії прокуратури України запроваджено підвищення їх кваліфікації.

Підвищення кваліфікації державних службовців органів прокуратури здійснюється відповідно до календарних планів підвищення кваліфікації прокурорів у Національній академії прокуратури України та планів набору слухачів для підвищення кваліфікації у Національній академії прокуратури України.

Відповідно до вимог до професійної компетентності осіб, що обіймають посади державних службовців органів прокуратури та із врахуванням пропозицій керівників регіональних та місцевих прокуратур, в Академії розроблено Професійну Програму підвищення кваліфікації державних службовців органів прокуратури, яка затверджена ректором академії та погоджена першим заступником Генерального прокурора i головою Національного агентства України з питань державної служби. 
Наулік Н., Горзов А.

Особливості правового статусу керівника державної служби в місцевій прокуратурі

Важливо пам'ятати, що керівник державної служби забезпечує професійне навчання державних службовців, вперше призначених на посаду державної служби, протягом року з дня їх призначення. На строк професійного навчання за державним службовцем зберігаються його посада та заробітна плата.

Керівник місцевої прокуратури повинен заохотити державних службовців за їх бездоганну та ефективну державну службу, за особливі заслуги. Це, як правило, може бути один з таки видів заохочень:

1) оголошення подяки;

2) нагородження грамотою, почесною грамотою, іншими відомчими відзнаками державного органу;

3) дострокове присвоєння рангу в порядку, визначеному цим Законом;

4) представлення до нагородження урядовими відзнаками та відзначення урядовою нагородою (вітальний лист, подяка, почесна грамота);

5) представлення до відзначення державними нагородами.

Державний службовець місцевої прокуратури має право оскаржити керівнику прокуратури порушення законодавчо наданих йому прав або виникнення перешкод у реалізації таких прав. Він може подати у місячний строк з дня, коли він дізнався або повинен був дізнатися про таке порушення, скаргу, в якій викласти факти порушення його прав або перешкод у їх реалізації, а також в ній може вимагати від керівника прокуратури утворення комісії для перевірки викладених у скарзі фактів.

Закон зобов’язує керівника місцевої прокуратури надати державному службовцю обгрунтовану письмову відповідь (рішення) не пізніше 20 календарних днів 3 дня отримання скарги. Якщо для розгляду скарги утворювалась комісія, то письмова відповідь (рішення) керівника прокуратури має грунтуватися на висновку комісії.

У разі неотримання в 20-денний строк обгрунтованої відповіді на скаргу або незгоди з відповіддю керівника державної служби державний службовець може звернутися із відповідною скаргою до Національного агентства України з питань державної служби або його територіальних органів.

Слід наголосити, що державного службовця місцевої прокуратури за невиконання або неналежне виконання посадових обов'язків, визначених Законом та іншими нормативно-правовими актами у сфері державної служби, посадовою інструкцією, а також порушення правил етичної поведінки та інше порушення службової дисципліни у порядку, встановленому Законом, може бути притягнуто до дисциплінарної відповідальності.

Підставою для притягнення державного службовця до дисциплінарної відповідальності є вчинення ним дисциплінарного проступку, тобто протиправної винної дії або бездіяльності чи прийняття рішення, що полягає у невиконанні або неналежному виконанні державним службовцем своїх посадових обов’ язків та інших вимог, встановлених Законом, та іншими нормативно-правовими актами, за яке до нього може бути застосоване дисциплінарне стягнення.

Керівник місцевої прокуратури або суб'єкт призначення може своїм рішенням відсторонити державного службовця від виконання посадових обов'язків на час здійснення дисциплінарного провадження. Під час відсторонення від виконання посадових обов’язків державний службовець зобов'язаний перебувати на робочому місці відповідно до правил внутрішнього службового розпорядку та сприяти здійсненню дисциплінарного провадження.

Висновки. Отже, досліджуючи особливості правового статусу керівника державної служби в місцевій прокуратурі, варто зауважити, що безпосередній керівник державного службовця та керівник місцевої прокуратури - поняття тотожні, які не можна розмежовувати, тобто державні службовці місцевої прокуратури безпосередньо підпорядковуються керівнику місцевої прокуратури. Однак за порушення прав державних службовців, керівник місцевої прокуратури нестиме відповідальність за Законом України «Про прокуратуру» (через Кваліфікаційно-дисциплінарну комісію прокурорів).

Крім того, доцільним є розглянути питання про запровадження в прокуратурі керівників державної служби (державних секретарів), які б не були наділені статусом прокурора, що дасть можливість уникнути певних колізій в законодавстві та розмежує поняття «керівник прокуратури» та «керівник державної служби».

\section{Список використаних джерел}

1. Про прокуратуру : Закон Украӥни від 14 жовтня 2014 р. // Відомості Верховної Ради Украӥни. - 2014. - № 22.

2. Конституція України // Відомості Верховної Ради. - 1996. -№ 30. - cm. 141 зі змінами та доповненнями від 30 вересня 2016 р. // Відомості Верховної Ради. - 2016. - № 28. - Cm. 532.

3. Про державну службу : Закон Украӥни від 1 грудня 2015 року // Відомості Верховної Ради України. 2016. - № 4. - Cm.43 
4. Великий тлумачний словник сучасної украӥнської мови / уклад. і голов. ред. В. Т. Бусел. - К.; Ірпінь : Перун, $2004-1840$ с.

5. Великий енциклопедичний юридичний словник / за ред. акад. НАН України Ю. С. Шемшученка. - К. : Юридична думка, 2007 р. - 992 с.

\section{References}

1. Zakon Ukrainy Pro prokuraturu: pryiniatyi 14 zhovt. 2014 roku № 22 [Law of Ukraine on On the Prosecutor's Office from October 14 2014, №22]. (2014, October 14). Vidomosti Verkhovnoi Rady Ukrainy - Bulletin of Verkhovna Rada of Ukraine. Kyiv: Parlam. vyd-vo [in Ukrainian].

2. Konstytutsiiya Ukrainy [Constitution of Ukraine]. (1996, June 28, № 30). [Constitution of Ukraine with amendments and supplements from September 30 2016, № 28]. Vidomosti Verkhovnoi Rady Ukrainy - Bulletin of Verkhovna Rada of Ukraine. Kyiv: Parlam. vyd-vo [in Ukrainian].

3. Zakon Ukrainy Pro derzhavnu sluzhbu: pryiniatyi 1 grud. 2015 roku № 4 [Law of Ukraine on civil service from December 1 2015, № 4]. (2015, December 1). Vidomosti Verkhovnoi Rady Ukrainy - Bulletin of Verkhovna Rada of Ukraine. Kyiv: Parlam. vyd-vo [in Ukrainian].

4. Busel, V.T. (2004). Velykyi tlumachnyi slovnyk suchasnoi ukrainskoi movy [Great explanatory dictionary of modern Ukrainian language]. Irpin: Perun [in Ukrainian].

5. Shemshuchenko, Yu.S. (2007). Velykyi entsyklopedychnyi yurydychnyi slovnyk [Great encyclopedic legal dictionary]. Kyiv: Yurydychna dumka [in Ukrainian].

Стаття надійшла до редакції 17.01.2018. 